\title{
Hazai Ipari Hulladékok Innovatív Hasznosítási Lehetőségei Építőanyagipari Célra
} Innovative Utilization Possibilities of Industrial Wastes from Hungary as Construction Industrial Material

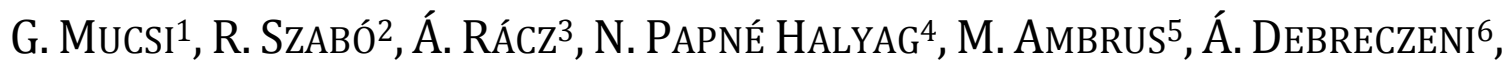 \\ F. MóRICZ7 , F. KRISTÁLY8
}

${ }^{1}$ Miskolci Egyetem, Műszaki Földtudományi Kar, Nyersanyagelőkészítési és Környezeti Eljárástechnika Intézet, ejtmucsi@uni-miskolc.hu

${ }^{2}$ Miskolci Egyetem, Műszaki Földtudományi Kar, Nyersanyagelőkészítési és Környezeti Eljárástechnika Intézet, ejtszabor@uni-miskolc.hu

${ }^{3}$ Miskolci Egyetem, Műszaki Földtudományi Kar, Nyersanyagelőkészítési és Környezeti Eljárástechnika Intézet, ejtracz@uni-miskolc.hu

${ }^{4}$ Miskolci Egyetem, Múszaki Földtudományi Kar, Nyersanyagelőkészítési és Környezeti Eljárástechnika Intézet, ejtpnora@uni-miskolc.hu

${ }^{5}$ Miskolci Egyetem, Műszaki Földtudományi Kar, Nyersanyagelőkészítési és Környezeti Eljárástechnika Intézet, maria.ambrus@uni-miskolc.hu

6Miskolci Egyetem, Műszaki Földtudományi Kar, Bányászati és Geotechnikai Intézet, bgtda@uni-miskolc.hu ${ }^{7}$ Miskolci Egyetem, Műszaki Földtudományi Kar, Ásványtani és Kőzettani Intézet, askmoricz@uni-miskolc.hu ${ }^{8}$ Miskolci Egyetem, Műszaki Földtudományi Kar, Ásványtani és Kőzettani Intézet, askkf@uni-miskolc.hu

Absztrakt. A Miskolci Egyetem Müszaki Földtudományi Karán müködő Fenntartható Természeti Erőforrás Gazdálkodás Kiválósági Központban elvégzett kutatások eredményei azt mutatják, hogy a megfelelő elókészítést alkalmazva és a körülményeket optimálva a hulladék alapanyagok eljárástechnikai jellemzőinek (szemcseméret eloszlás, fajlagos felület) megváltoztatásával az építőanyag termékek fizikai és mechanikai tulajdonságai (szilárdság, tömörség) javíthatók. Kutatásaink ugyanis kimutatták, hogy a kémiai aktiválás mellett a mechanikai aktiválás is egy igen hatékony eszköz a tulajdonságok szabályozására. Ez azonban megváltoztatja nemcsak a termék fizikai, mechanikai, hanem a szerkezeti, ásványtani jellemzôit is, ezért ezen jellemzôk meghatározása is kiemelten fontos.

Abstract. The research results carried out at the University of Miskolc Faculty of Earth Science and Engineering in the Center of Excellence of Sustainable Natural Resource Management show that the physical and mechanical properties of the construction industrial products (strength, compactness) made of waste sources can be controlled reasonably by the appropriate processing technologies and under optimized circumstances and characteristics (particle size distribution, specific surface area). It was established that beside the chemical activation, the mechanical activation of solids is an effective tool for improving the product characteristics. However, this modifies 
the physical as well as structural, mineralogical properties of the raw materials, therefore its determination is of great importance.

\section{Bevezetés}

A Föld egyre gyarapodó lakosságának folyamatosan növekvő energiaigénye hatására egyre több energetikai hulladék keletkezik a szilárd tüzelésű erőművekben, javarészt erőműi pernye és salak, valamint füstgáz kéntelenítési gipsz. Egyes források szerint ezek évente keletkező mennyisége világviszonylatban eléri a 800 millió tonnát [1]. Emellett hasonló volument tesz ki a vas és acélgyártási salak (600 millió tonna), és a különböző bányászati hulladékok. Ennek a világméretű problémának a megoldására az Európai Unió direktívái arra sarkallják a tudósokat, hogy új technológiákat és ezáltal nagy hozzáadott értékű termékeket fejlesszenek ki a fenti melléktermékekből, hulladékokból. Ezt mondja ki a közelmúltban elfogadott Körkörös Gazdaság (Circular Economy) modell is, amely egyik fő pontja a hulladékok hasznosítása. A szóban forgó melléktermék nyersanyagként történő hasznosítása az általa kiváltott elsődleges ásványkincseinkkel, nyersanyagainkkal történő racionális és fenntartható gazdálkodást jelentené. Végül, de nem utolsó sorban pedig a $\mathrm{CO}_{2}$ kibocsátás csökkentéséhez is hozzájárul, mivel a kiváltandó cement előállításakor jelentős mennyiségű $\mathrm{CO}_{2}$ keletkezik. Tanulmányunk a Föld legnagyobb mennyiségben keletkező ipari hulladékainak jellemzőit és hasznosítási lehetőségeit ismerteti elsősorban saját hazai kutatások eredményein keresztül, nevezetesen erőműi pernyére, vörösiszapra és acélgyártási salakra fókuszálva geopolimer fejlesztés vonatkozásában.

\section{Irodalom bemutatása}

\subsection{Ipari hulladékok}

\subsubsection{Erőmüi pernyék}

A villamosenergia termelésében a széntüzelésű erőművek világszerte jelentős szerepet töltenek be. A kőolaj és földgáz után a harmadik helyen áll az energiaforrások sorában, de Ázsiában vannak olyan országok, ahol a szénalapú energiatermelés meghaladja az 50 \%-ot, ugyanez az érték Európában és Észak-Amerikában kb. 18 \%, Afrikában pedig 23 \% körüli [2]. A szilárd égési maradványanyag durva része a kazán salak, amely a kazán alsó részén kerül kihordásra. A finom frakció pedig a füstgázzal együtt távozik a kazánból, amely egy mechanikai és/vagy elektrosztatikus porleválasztást követően kerül összegyűjtésre. A mechanikai porleválasztás eszköze lehet pl. az ülepítőkamra, a porciklon, az örvénycsöves vagy a kerámiagyertyás pernyeleválasztó, melyek legtöbbször előleválasztó szerepet töltenek be, vagyis a pernye durvább és nehezebb szemcséit gyűjtik össze. Az elektrosztatikus porleválasztás eszközei a különböző kialakítású elektrofilterek, amelyekben a finomabb és könnyebb pernye szemcsék leválasztása történik. A nagy kéntartalmú szenek esetében a füstgázt ezt követően egy abszorberre vezetik, ahol legtöbbször mészkő zaggyal (vagy mésztejjel) kéntelenítik. Ennek a folyamatnak a mellékterméke az ún. füstgáz kéntelenítési gipsz. 
A pernye fóként szilícium-oxidot, alumínium-oxidot és kisebb mennyiségú vas-oxidot, kalcium-, magnézium és mangán-oxidot tartalmaz. Fázisait tekintve elsősorban az üveges komponensek vannak túlsúlyban, de kristályos komponensei közül a mullit, a kvarc, a magnetit és a hematit is megtalálható. A kémiai és ásványos összetétel elsősorban attól függ, hogy milyen szén kerül elégetésre, illetve a szén lelőhelyén a szénen kívül milyen kőzetek fordulnak elő, de kiemelt jelentőséggel bír a szén előkészítése, az égetés módja, tüzeléstechnikai paraméterei és a szilárd részecskéknek a füstgáz áramából történő leválasztása.

\subsubsection{Kohászati salakok}

A kohászati salakok az ércek meddő alkotórészeinek, valamint a fémolvadékokból eltávolítandó nem kívánatos elemeknek folyékony állapotban keletkező, majd megdermedő keveréke. A salakok a vaskohászat működése során keletkező, nem a termelés célját jelentő anyagok döntő többségét (8590\%-át) teszik ki, így mennyiségük alapján törekedni kell minél teljesebb mértékű hasznosításukra [3,4]. Tulajdonságaik, valamint különféle célokra (a fejlett országok gyakorlata alapján bizonyított) alkalmasságuk miatt a vaskohászati salakoknál tolódik el leginkább a határvonal a „hulladék” megítéléstől a „melléktermék” megnevezés irányába.

A vaskohászati salakok keletkezésüktől függően az alábbi módon csoportosíthatók:

- Nagyolvasztói salakok vagy kohósalakok: Ca-Al-Mg szilikátok, a bazalthoz hasonlóak, stabil szerkezet és kémiai összetétel, megfelelő szilárdság, nagy vastartalom jellemző őket.

- Konverteres acélművi salakok: nagyobb $\mathrm{CaO}$, kisebb $\mathrm{SiO}_{2}$ tartalom, összetétel szélesebb határok közt változik, kezelendő a szabad $\mathrm{CaO}$ tartalom, ami duzzadást okozhat. Emiatt pihentetés (6-12 hónap), vagy mesterséges öregítés (hőkezelés) szükséges. Szerkezete tömör, szilárdsága nagy.

- Elektroacél-gyártási salakok: esetenként vízben oldható nehézfémeket tartalmaznak, ami felhasználási korlát.

- Üstmetallurgiai salakok, az előzőhöz hasonlóan korlátok jelentkeznek.

\subsubsection{Vörösiszapok}

Világviszonylatban 120 millió tonna vörösiszap keletkezik, valamint 2,7 milliárd tonna a lerakott iszap tömege, hazánkban kb. 50 millió tonna vörösiszap van, amelynek hasznosítása jelenleg nem megoldott. Lengyel és Lakatos [5] összefoglalta a vörösiszap hasznosításának lehetőségeit. Az építőiparban cementgyártásnál, tégla, blokktégla építőelemek, geopolimerek előállításánál; vegyiparban katalizátorok, szorbensek, kerámiák, bevonatok, műanyag töltőanyagok, pigment gyártásánál; környezetvédelemben szennyezett és savas bányavizek, szennyezett talajok, savas füstgázok kezelésénél; mezőgazdaságban talajadalékként (pH beállítására); metallurgiában acélgyártáshoz, fém visszanyerésnél (mivel pl. a hazai vörösiszapokból vasat és alumíniumot lehet kinyerni). A vörösiszap alkalmazhatósága korlátozott köszönhetően magas vastartalmának, az alkálifémek jelenlétének és kis szemcseméretének. A felhasználását célzó korábbi kutatások tégla, kerámiák, cement, falicsempék készítésében és a fémkinyerésben vélték a probléma megoldását, azonban ezek egyike sem bizonyult járható útnak egy széles körben elfogadott technológia megvalósításában. A geopolimerizáció azonban 
egy potenciális hasznosítási lehetőséget kínál, mivel a vörösiszap $\mathrm{Al}_{2} \mathrm{O}_{3}$-at, $\mathrm{SiO}_{2}$ - $\mathrm{t}$ és marónátront tartalmaz, amelyek a geopolimerizáció szempontjából fontosak. Geopolimerbe történő befoglalás esetén a vörösiszapban lévő toxikus anyagok stabilizációja is megvalósulhat.

\subsection{Geopolimerek}

A geopolimerek amorf alumino-szilikátok, melyek lúgos közegben $(\mathrm{KOH}, \mathrm{NaOH})$ szilícium-dioxid és alumino-szilikát-oxidok között lejátszódó reakció során állíthatóak elő szobahőmérsékleten vagy magasabb hőmérsékleten $\left(30-100^{\circ} \mathrm{C}\right)$ egyaránt. Ez a reakció egy amorf félig-kristályos háromdimenziós polimer struktúrát eredményez, mely Si-O-Al kötésekből áll [6, 7]. Minden olyan elsődleges vagy másodlagos nyersanyag alkalmas geopolimer gyártására, amely reaktív szilíciumdioxid és alumínium-oxid fázisokat tartalmaz, mint pl. a természetes kőzetek vagy ipari melléktermékek: kaolin, erőműi pernye, kohászati salak és vörösiszap [6,7,8,9]. A geopolimerek jó fizikai-kémiai és mechanikai tulajdonságokkal rendelkeznek, többek között alacsony sűrűség, mikrovagy nanoporozitás, csekély zsugorodás, magas szilárdság, hőstabilitás, nagy felületi keménység, tűz és kémiai ellenálló képesség jellemzi [10,11,12]. Az erőműi pernye a geopolimerek potenciális nyersanyaga lehet, a bennük lévő $\mathrm{SiO}_{2}$ és $\mathrm{Al}_{2} \mathrm{O}_{3}$, mint fő alkotórészek jelenlétének köszönhetően [7]. Korlátozó tényező a pernye használatát illetően, annak alacsony reaktivitása, mely hátráltatja (lassítja) a geopolimerizációt. A pernye reakcióképessége függ annak szemcseméret-eloszlásától, fajlagos felületétől, ásványos fázisoktól és az amorf fázisok mértékétől is [13,14,15].

A hőmérséklet emelkedésének reakciógyorsító hatása van, továbbá Palomo et al. szerint [16] a hőmérséklet növelése a mechanikai szilárdságban javulást eredményez. Chindraprasirt et al. [17] kimutatták, hogy amikor a hőkezelési hőmérséklet magas, a minta nedvességtartalmának jelentős csökkenése figyelhető meg, ami kedvezőtlenül befolyásolta a szilárdságot. A magas szilárdság elérése érdekében azonban a geopolimerizációs reakció nedvesség jelenlétét igényli.

\section{Kutatási eredmények}

A kutatási eredményeket három területre fókuszálva mutatjuk be a következőkben: (1) erőműi pernye - kohászati salak alapú geopolimer beton, (2) erőműi pernye - vörösiszap alapú geopolimer kötőanyag és (3) erőműi pernye - polisztirol alapú geopolimer könnyűbeton fejlesztése.

\subsection{Erőmúi pernye - kohászati salak alapú geopolimer beton}

Pernye - kohászati salak együttes hasznosítása tekintetében egy korábbi tanulmányunk szerint [18] a pernye alapú geopolimer sikeresen alkalmazható konverteres salakból előállított aggregátummal „zöld” beton fejlesztés céljából. Az erőműi pernye a Mátrai Erőműből a kohászati salak pedig a Dunaújvárosi Acélműből származott.

Elsőként a geopolimer kötőanyagot fejlesztettük. A nyomószilárdság értékek (1. ábra) alapján látható, hogy a vízüveg mennyiségének növelése a geopolimerek szilárdságának javulását eredményezte. Az ábrán az is megfigyelhető, hogy a vízüvegtartalom mellett a geopolimer kezelési hőmérséklete is 
fontos szerepet játszik. A vízüvegtartalom növelésével az alacsonyabb hőmérsékleten kezelt geopolimerek rendelkeztek magasabb szilárdságértékkel. A legnagyobb szilárdságot a 100\% vízüvegtartalom és $30^{\circ} \mathrm{C}$-on való hőkezelés eredményezte (21,3 $\left.\mathrm{MPa}\right)$.

Ezután az optimális beállítások és geopolimer kötőanyag összetétel ismeretében elkezdtük a salak adagolása mellett a beton fejlesztési kísérleteket. A 2. ábra jól szemlélteti, hogy alacsony (15\%) kötőanyag tartalom nem volt elegendő az aggregátumok közötti pórustér kitöltéséhez.

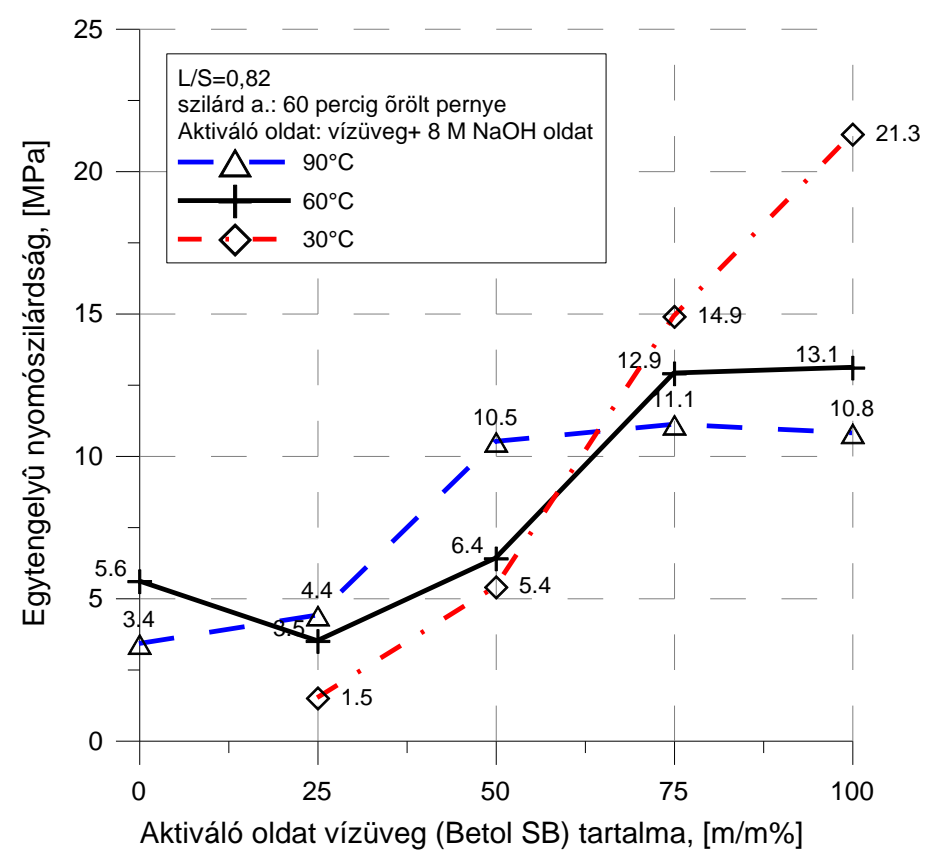

1. ábra. A nyomószilárdság és az aktiváló oldat vízüveg tartalma közötti összefüggés [18]

Nagyobb kötőanyagtartalom (30\%) az aggregátumok közötti teret teljes mértékben kitöltötte, az így kapott geopolimer beton tömör szerkezettel rendelkezett (2. b. ábra).

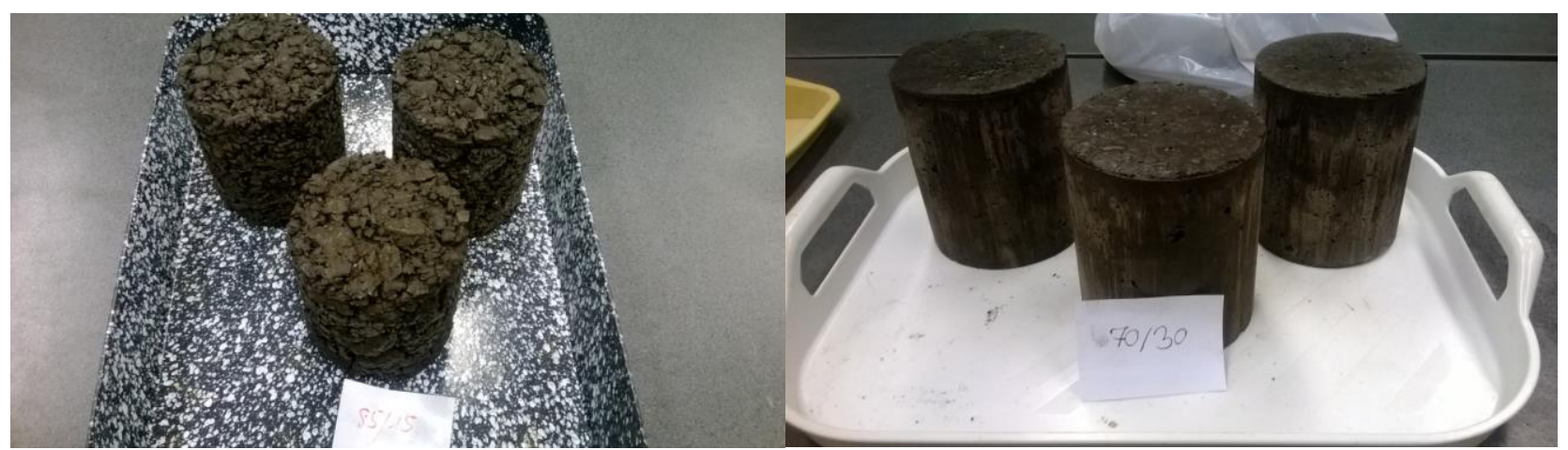

a

b

2. ábra. Geopolimer beton termékek 85/15 (a) és 70/30-as (b) adalékanyag/kötőanyag aránynál [18]

A 3. ábra reprezentálja, hogy a legnagyobb nyomószilárdságot az adalékanyag/kötőanyag 80/20-as aránya mellett mértünk (19,2 MPa), viszont ennél az aránynál készült keverék bedolgozhatósága kedvezőtlenebb lett, mint a többi esetben. 
A vizsgálatok során arra a következtetésre jutottunk, hogy a bedolgozhatóság szempontjából legideálisabb keverék a 75/25, illetve a 70/30 adalékanyag/kötőanyag aránynál tapasztalható, valamint a 70/30-as aránynál a 80/20-as arányhoz hasonló nyomószilárdságú próbatest (18,6 MPa) állítható elő.

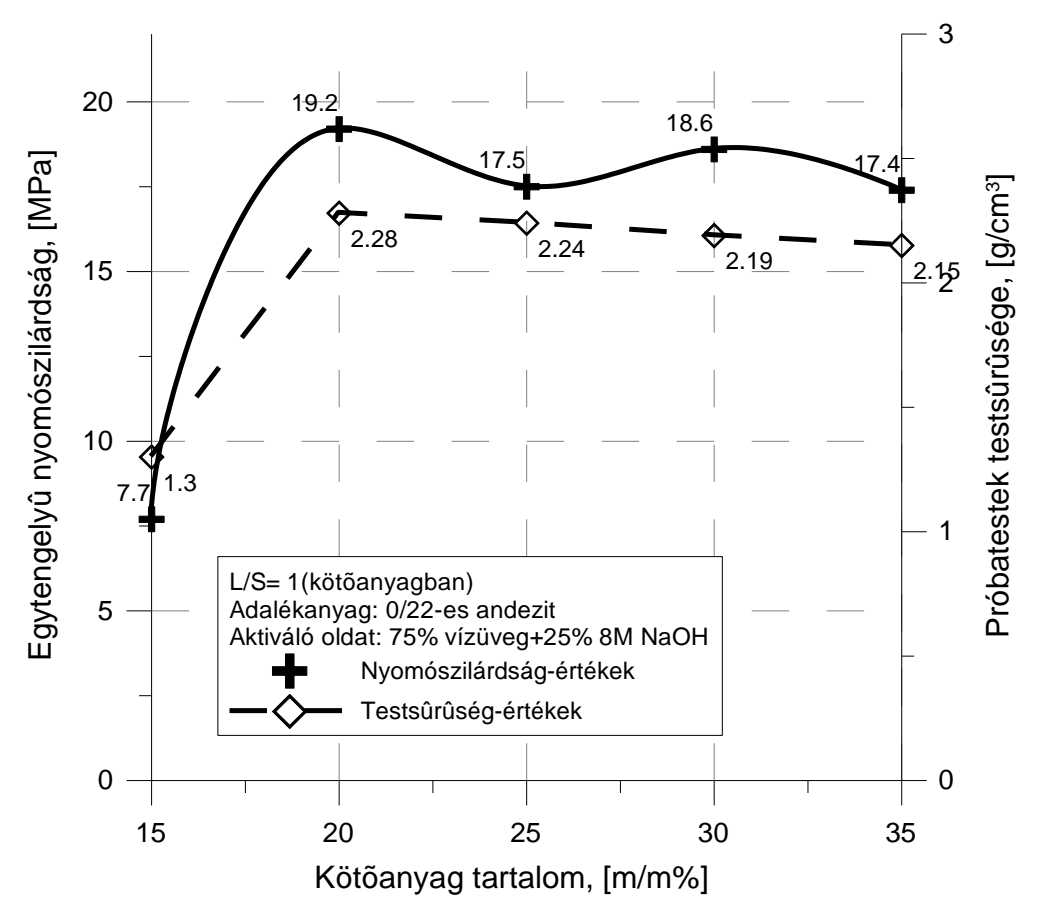

3. ábra. Geopolimer beton nyomószilárdság és testsưrüségének változása a kötőanyag tartalom függvényében

$$
(L / S=1)[18]
$$

\subsection{Erőműi pernye - vörösiszap alapú geopolimer kötőanyag}

A vörösiszap magas Na tartalma és pH értékének köszönhetően kiválthatja a geopolimer előállításához szükséges lúgos aktiválószer egy részét. Ezzel összefüggésben egy korábbi kutatásunkban [19, 20] végzett kísérlet során vizsgáltuk az almásfüzitői vörösiszap pernye geopolimer tulajdonságaira gyakorolt hatását. Állandó szilárdanyag tartalom mellett a pernye összetevőt helyettesítettük 0; 5; 10; 20 és 40 m/m\%-ban vörösiszappal. 


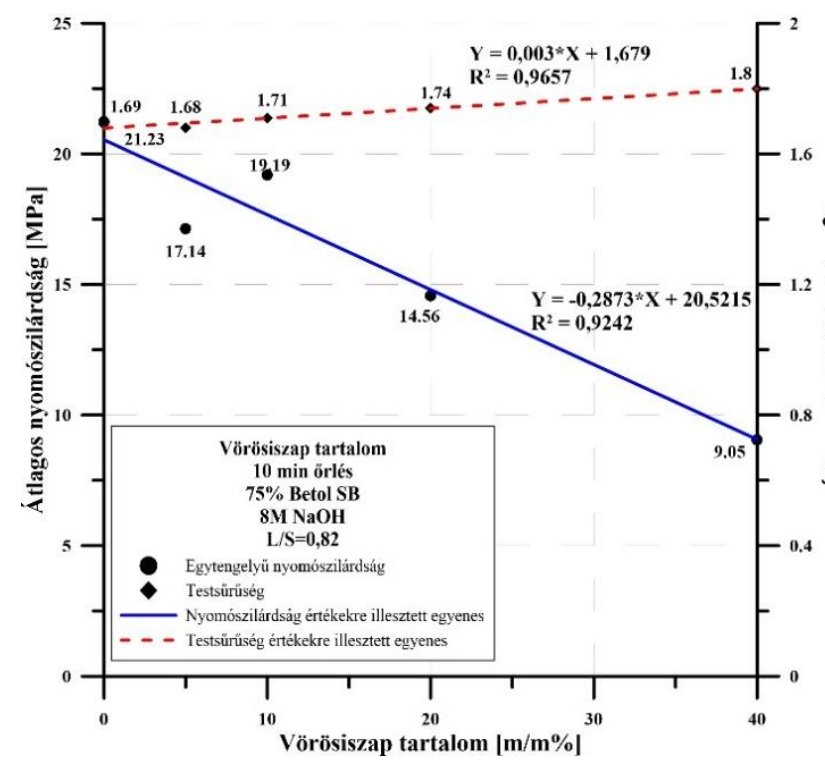

a

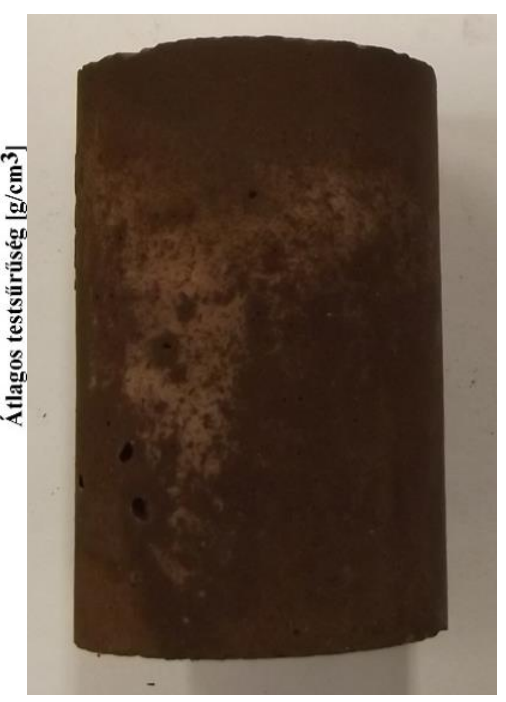

b

4. ábra. Vörösiszap adagolás hatása a geopolimer szilárdságára és testsûrűségére (a), geopolimer próbatest (b) [19, 20]

A kísérleti eredményeket mutatja a 4. ábra, ami alapján megállapítható, hogy a geopolimer szilárdsága vörösiszap nélkül több mint $20 \mathrm{MPa}$ értéket ért el. A szilárdság fokozatosan csökkent a vörösiszap arány emelkedésének hatására, a testsűrűség pedig csökkent. Az 5, 10 és 20 \%-os vörösiszap adagolás esetében az egytengelyű nyomószilárdság csökkent, de a 15-20 MPa tartományban maradt, ami a tégla szilárdsági értékeit felülmúlja. A 40 \% adagolásnál viszont a szilárdság jelentősen visszaesett, de még így is 9 MPa értéket vett fel.

\subsection{Erőműi pernye - polisztirol alapú geopolimer könnyűbeton}

Kutatási eredményeink alapján [21] a geopolimer jó lángálló képességének köszönhetően alkalmas lehet például éghető hőszigetelő anyagok bevonatolására, így hőszigetelő panelek gyártására. A geopolimer (GP) polisztirol (PS) kompozit nyomószilárdsága alapvetően a két komponens arányától függ, ahogy a testsűrűség értéke (a próbatest tömörsége) is nagymértékben ezen múlik.

Azt tapasztaltuk, hogy kompozit szilárdsági jellemzői (5. ábra) meghaladhatják a kiindulási polisztirol hasonló mutatóit [21]. A komponensek ideális keverési aránya meghatározható, természetesen más egyéb tényezőket is figyelembe véve, mint például a hőszigetelő képesség vagy a lángállóság. 

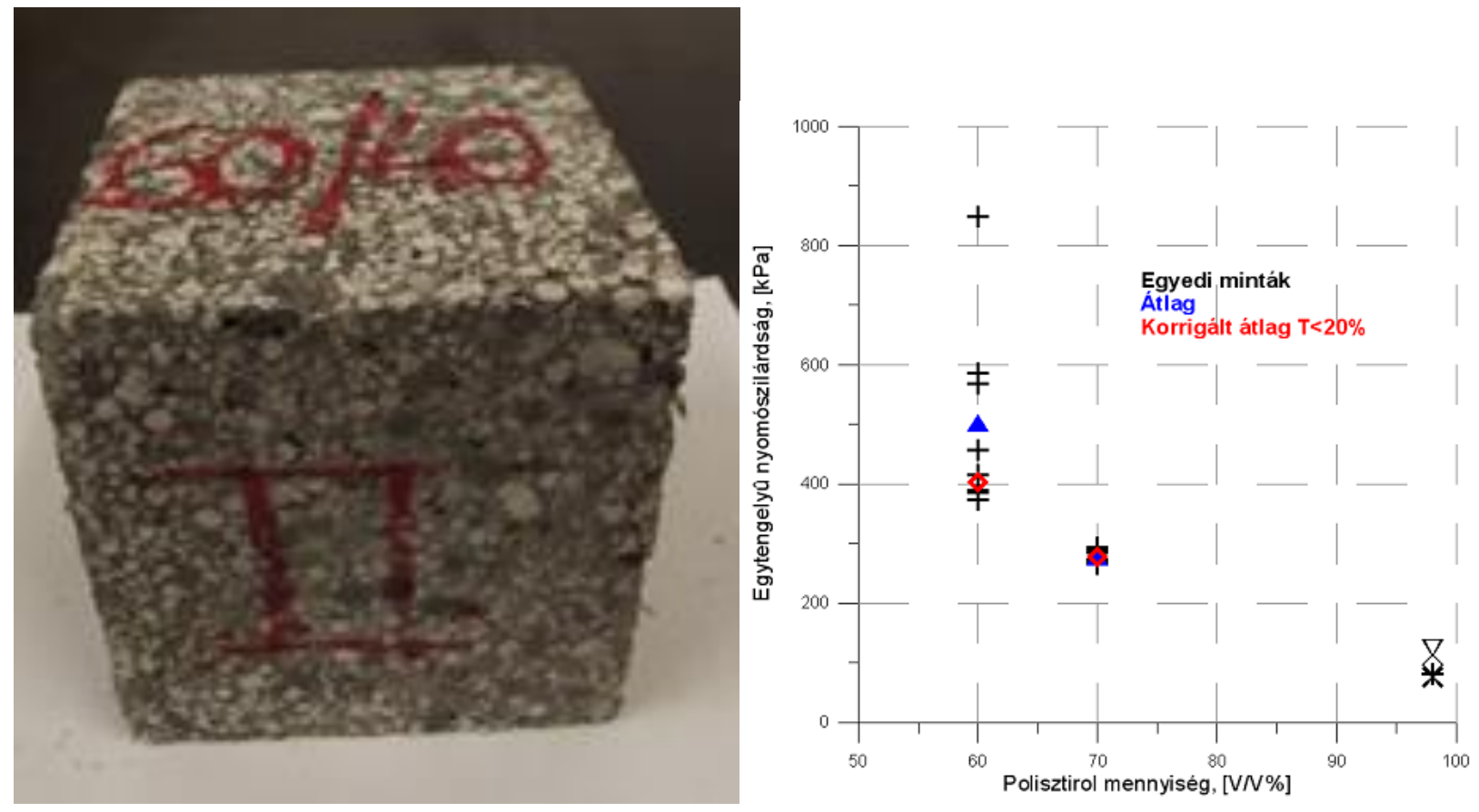

5. ábra. Pernye geopolimer - polisztirol kompozit (a) és a kompozit nyomószilárdsága (b) [21]

Lángállóság vizsgálatát is elvégeztük a vizsgálatsorba bevont építőipari alapanyagokon (6. ábra). Lángot egy szabályozható gázégővel állítottunk elő, míg a próbatestet egy megfelelő állványzat segítségével pozicionáltuk a lángba. A vizsgálat végén a próbatestet szemrevételeztük, a lepergő, lecsepegő termék tömegét mértük.

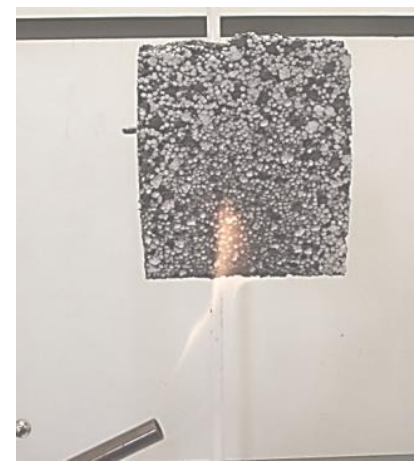

a)

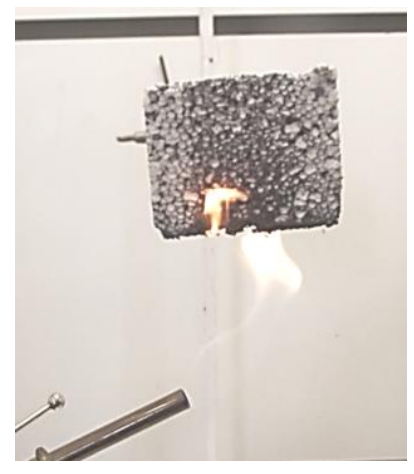

b)

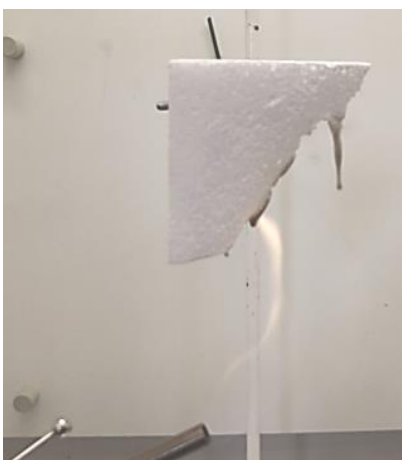

c)

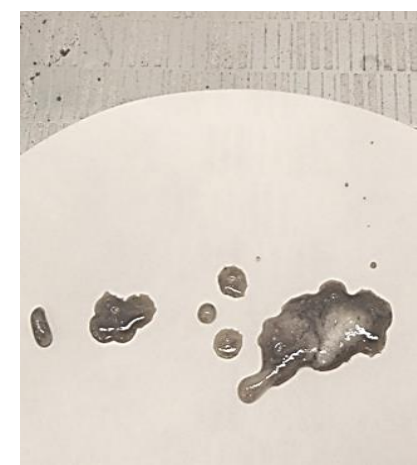

d)

6. ábra. A lángállósági vizsgálatok felvételei: a) PS tartalom $90 \mathrm{~V} / \mathrm{V} \%$, b) PS $98 \mathrm{~V} / \mathrm{V} \%$, c) PS $100 \mathrm{~V} / \mathrm{V} \%$, d) $100 \mathrm{~V} / \mathrm{V} \% \mathrm{PS}[21]$

A kísérletek alapján megállapítható, hogy egyik minta esetén sem gyulladt be a minta alá helyezett szűrőpapír. A 100 V/V\% EPS-sel szemben nyilvánvaló, hogy a geopolimer tartalom a minta roncsolódását gátolja. Megállapítható, hogy a vizsgált minták közül a 60...94\% EPS tartalom közöttiek a vizsgálat során nem lángoltak, nem növelték a lángnyelv hosszát. 


\section{3. Összegzés}

A végrehajtott kutatómunka során különböző ipari termelés során, nagy tömegben keletkező melléktermékek (hulladékok) hasznosítását vizsgáltuk egy újfajta kötőanyag, nevezetesen geopolimer alapanyagaként. Széntüzelésű erőműi pernye, acélgyártási konverter salak és vörösiszap mintaanyagokat vontunk a vizsgálatokba. A kísérleti eredmények alapján megállapítható, hogy ezen anyagok együttes hasznosítása csökkentheti az előállítási költségeket és javítja a végtermék tulajdonságait (szilárdság, lángállóság).

\section{Köszönetnyilvánítás}

A tanulmány/kutatómunka a Fenntartható Nyersanyag-gazdálkodási Tematikus Hálózat - RING 2017 című, EFOP-3.6.2-16-2017-00010 jelű projekt részeként a Széchenyi2020 program keretében az Európai Unió támogatásával, az Európai Szociális Alap társfinanszírozásával valósult meg.

\section{Hivatkozások}

[1] C., Heidrich, J. J., Feuerborn, A., Weir, 2013. Coal combustion products: a global perspective. In: World of Coal Ash Conference. 2013. April 22e 25. In Lexington KY. pp. 25-35.

[2] Mucsi, Gábor (szerk.) Erőműi pernye komplex hasznosítása. Miskolc, Magyarország: Milagrossa Kft. (2014), p. 218

[3] Márkus R.: Acélgyártási salakok környezetbarát hasznosítási lehetôségeinek elméleti alapjai, és megvalósíthatósága egyes részeinek kidolgozása. Doktori Disszertáció, Miskolci Egyetem, 2009.

[4] Ézsiás L., Hevesiné Kővári É., Tóth A. (2012): Kohászati salakok: a természetes kőzetek alternatívái az aszfaltgyártás területén. ISD DUNAFERR MÛSZAKI GAZDASÁGI KÖZLEMÉNYEK, 5. évfolyam 2. szám (165) pp. 93-97.

[5] Lengyel A., Lakatos J. - Vörösiszap hasznosításának lehetöségei, Anyagmérnöki Tudományok, Miskolc, 36/1. kötet., (2011) pp. 35-48.

[6] Davidovits J. 2011. Geopolymer chemistry and application. Published by: Institut Geopolimére 16 rue Galilée F-02100 Saint-Quentin France, ISBN: 9782951482050, pp. 283, 286.

[7] Davidovits J. 1994 Geopolymers: inorganic polymeric new materials. J. Mater. Educ. 16, pp. 91139.

[8] Komintsas K., Zaharaki D. 2007. Geopolymerisation: A review and prospects for the mineral industry. Mineral Engineering 20 pp. 1261-1277.

[9] Mucsi G., Lakatos J., Z. Molnár J., Szabó R. 2014. Development of geopolymer using industrial waste materials. The 9th International Conference "ENVIRONMENTAL ENGINEERING"

[10] Barbosa V. F. F., MacKenzie K. J. D., Thaumaturgo C. 1999. Synthesis and characterization of sodium polysialate inorganic polymer based on alumina and silica. In Geopolymer '99 Second International Conference, Saint-Quentin, France, 1999. pp. 65-78.

[11] Barbosa V.F.F., MacKenzie K.J.D. 2003: Thermal behaviour of inorganic geopolymers and composites derived from sodium polysialate Mater. Res. Bull., 38, pp. 319-331. 
[12] Panias D., Giannopoulou I. P., Perraki T. 2007. Effect of synthesis parameters on the mechanical properties of fly ash-based geopolymers. Colloids and Surfaces A: Physicochem. Eng. Aspects; 301 pp. 246-254.

[13] Kumar S., Kumar R. 2011. Mechanical activation of fly ash: Effect on reaction, structure and properties of resulting geopolymer. Ceramics International 37 pp. 533-541.

[14] Kumar S., Kumar R., Alex T. C., Bandopadhyay A., Mehrotra S. P. 2007. Influence of reactivity offly ash on geopolymerisation. Advances in Applied Ceramics vol. 106, No 3 pp. 120-127.

[15] Kumar R., Kumar S., Mehrotra S.P. 2007. Towards sustainable solutions for fly ash through mechanical activation. Resources, Conservation and Recycling 52 pp. 157-159.

[16] Palomo A., Grutzeck M. W., Blanco., M. T. 1999. Alkali activated fly ashes A cement for the future. Cem. Concr. Res. 29 pp. 1323-1329.

[17] Chindaprasirt P., Chareerat T., Sirivivatnanon V.: 2007. Workability and strength of coarse high calcium fly ash geopolymer. Cem. and Conc. Composites, 29, pp. 224-229.

[18] Mucsi G., Rácz Á., Molnár Z., Szabó R., Gombkötő I., Debreczeni Á. 2014. Synergetic use of lignite fly ash and metallurgical converter slag in geopolymer concrete. Mining Science, 21, pp. 43-55.

[19] G Mucsi, R Szabo, Á Racz, Z Molnar, F Kristály, S Kumar: Influence of red mud on the properties of geopolymer derived from mechanically activated lignite fly ash. Bauxite Residue Valorisation and Best Practices Conference. Leuven, Belgium, 2015, pp. 211-218.

[20] G Mucsi, R Szabó, M Ambrus, B Kovács: The development of fly ash-red mud based geopolymer. Analecta Technica Szegedinensia, 2018. 12 (1), pp. 30-38.

[21] G Mucsi, R Szabó, S Nagy, K Bohács, I Gombkötő, Á Debreczeni: Development of polystyrenegeopolymer composite for thermal insulating material and its properties with special regards to flame resistance. IOP Conference Series: Materials Science and Engineering 251 (1), 012079 